\title{
SYSTEMATIC REVIEW: KUALITAS HIDUP PASIEN GAGAL JANTUNG KONGESTIF
}

\author{
Ance M. Siallagan \\ STIKes Santa Elisabeth Medan, Indonesia \\ Email: siallagan.ance@yahoo.com
}

\begin{abstract}
ABSTRAK
Gagal jantung kongestif adalah penyakit dengan prognosis yang buruk dan merupakan salah satu penyebab individu sering di rawat di rumah sakit, kualitas hidup yang rendah, serta harapan hidup yang lebih pendek dan tingkat kejadian penyakit bahkan kematian yang semakin tinggi. Pasien gagal jantung kongestif mengalami kelelahan dan sesak nafas yang berkontribusi memperburuk dan berdampak negatif terhadap kualitas hidup pasien. Systematic review ini bertujuan untuk menggali informasi tentang kualitas hidup pasien gagal jantung kongestif tahun 2020. Rancangan penelitian yang digunakan adalah penelitian deskriptif dengan metode systematic review. Peneliti mengumpulkan beberapa jurnal terkait topik melalui penulusaran dari database online proquest dan google scholar untuk di telaah dan di analisis. Berdasarkan analisis jurnal maka ditemukan sebanyak 6 jurnal (75\%) yang mengatakan bahwa kualitas hidup pasien gagal jantung kongestif buruk. Diharapkan dengan memberikan edukasi mampu membantu untuk meningkatkan pengetahuan pasien gagal jantung kongestif tentang manajemen diri yang baik sehingga kemampuan manajemen diri pasien gagal jantung kongestif akan meningkat dan dapat membantu individu untuk meningkatkan kualitas hidupnya.
\end{abstract}

Kata kunci : Kualitas hidup, gagal jantung kongestif

\section{PENDAHULUAN}

Gagal jantung merupakan salah satu penyebab individu sering di-rawat di rumah sakit, dengan kualitas hidup yang rendah, serta harapan hidup yang lebih pendek dan tingkat kejadian penyakit bahkan kematian yang semakin tinggi. Risiko kejadian penyakit gagal jantung terhadap setiap individu semakin meningkat seiring dengan bertambahnya usia [1]. Ameri-can College of Cardiology Founda-tion / American Heart Association (ACC / $A H A)$ menyebutkan bahwa gagal jantung merupakan suatu sindrom yang dihasilkan dari gang-guan fungsional atau struktural jan-tung yang merusak kemampuan ventri kel untuk menerima dan menyalurkan darah [2]. Gagal jantung adalah suatu kondisi yang terjadi ketika jantung tidak dapat berespons secara adekuat terhadap stres untuk memenuhi kebutuhan metabolik tubuh. Pada kondisi ini, jantung tidak mampu untuk melaksanakan tugasnya sebagai pemompa darah. Gagal jantung kongestif adalah keadaan ketika jantung tidak mampu lagi memompakan darah secukupnya dalam memenuhi kebutuhan sirkulasi tubuh untuk keperluan metabolisme jaringan 
tubuh pada kondisi tertentu, sedangkan tekanan pengisian ke dalam jantung masih cukup tinggi [3].

Gagal jantung merupakan masalah yang berkembang di seluruh dunia dengan jumlah kurang lebih dari 26 juta orang yang terkena dampaknya. Populasi orang dewasa yang menderita gagal jantung kongestif di negara maju dari prevalensi $1-2 \%$ meningkat menjadi $>10 \%$ di antara orang-orang yang berusia lebih dari 70 tahun. Pasien dengan gagal jantung hampir semua diperkirakan akan meninggal dalam lima tahun, dan gagal jantung merupakan penyebab rawat inap paling sering pada individu yang berusia lebih dari 65 tahun [4]. Di Amerika terdapat 6,5 juta orang Amerika memiliki riwayat gagal jantung. Ada 960.000 kasus gagal jantung baru yang di diagnosis setiap tahunnya di Amerika Serikat. Sekitar $50 \%$ pasien gagal jantung meninggal dalam kurun waktu 5 tahun setelah di diagnosis [5].

Prevalensi penyakit gagal jantung di Indonesia berdasarkan diagnosis dokter sebesar 0,13\% atau diperkirakan sekitar 229.696 orang, sedangkan berdasarkan diagnosis dokter/ gejala sebesar $0,3 \%$ atau diperkirakan sekitar 530.068 orang. Jumlah penderita penyakit gagal jantung terbanyak terdapat di Provinsi Jawa Timur sebanyak 54.826 orang $(0,19 \%)$, sedangkan Provinsi Maluku Utara memiliki jumlah penderita paling sedikit, yaitu sebanyak 144 orang $(0,02 \%)$ [6]. Angka kejadian gagal jantung kongestif di Sumatera Utara periode Juli hingga Desember tahun 2016 paling tinggi terjadi pada kelompok usia 56-65 tahun sebanyak 30 orang $(32.9 \%)$ dengan jumlah laki-laki 70 orang (77\%) dan wanita 21 orang $(23 \%)$ dan dengan klasifikasi gagal jantung kelas II dengan jumlah $46(51,1 \%)$ [7].

Gagal jantung kongestif merupakan penyakit dengan prognosis yang buruk. Pasien gagal jantung kongestif mengalami kelelahan dan sesak nafas yang berkontribusi memperburuk dan berdampak negatif terhadap kualitas hidup pasien [8] Penyakit gagal jantung merupakan salah satu penyakit yang dapat mengakibatkan berbagai kerusakan misalnya kerusakan pada baroreflek arteri yang berdampak pada kualitas hidup klien [9].

Kualitas hidup pasien gagal jantung dipengaruhi oleh banyak faktor termasuk manajemen diri. Manajemen diri yang baik dapat meningkatkan kualitas hidup, mengurangi rehospitalisasi, dan dapat mengurangi biaya perawatan [10]. Kualitas hidup pasien gagal jantung juga dapat dipengaruhi oleh lama pasien menderita sakit dan menjalani pengobatan, tingkat pendidikan, status pekerjaan, penyebab gagal jantung, serta dukungan yang kurang dari keluarga [11].

Sekitar $63,2 \%$ pasien gagal jantung kronik di Manado memiliki kualitas hidup kurang baik. Hal ini disebabkan oleh ketidakmampuan fungsional dan stress psikologis seperti depresi, cemas dan disforia yang disebabkan oleh kondisi penyakit kronis [12]. Frekuensi kualitas hidup dari 79 responden (pasien gagal jantung) di provinsi Lampung tahun 2017 dengan kategori rendah sebanyak 42 responden (53,2\%). Penelitian yang dilakukan oleh Wahyuni dan Kurnia (2014), dari 73 orang pasien dengan gagal jantung kongestif, pasien dengan kualitas hidup yang kurang baik sebanyak 40 orang $(54,8 \%)$. Berbagai faktor pemicunya 
adalah responden memiliki aktivitas yang hanya duduk atau tiduran sepanjang hari karena merasa sakit, mengalami kesulitan saat berjalan atau naik tangga, dan kesulitan tidur pada malam hari.

Berdasarkan latar belakang di atas, peneliti menggali atau mengumpulkan informasi yang berkaitan dengan Kualitas Hidup Pasien Gagal Jantung Kongestif. Penelitian terkait topik akan dilakukan analisis melalui Systematic review.

\section{METODE PENELITIAN}

Jenis rancangan penelitian yang digunakan dalam penelitian ini adalah rancangan penelitian systematic review yakni menulis ringkasan berdasarkan masalah penelitian. Systematic review ini akan diperoleh dari penelusuran jurnal penelitian-penelitian ilmiah dari rentang tahun 2010-2019 dengan menggunakan database Google Schoolar dan Proquest dengan kata kunci quality of life, congestive heart failure. Populasi dalam systematic review ini adalah seluruh jurnal yang terdapat di google scholar maupun proquest dengan kata kunci self management, quality of life, congestive heart failure. Dalam hasil pencarian, ditemukan sekitar 101.621 jurnal terkait kualitas hidup pasien gagal jantung kongestif. Adapun kriteria inklusi yang telah ditetapkan oleh peneliti, antara lain :

1. Jurnal yang di publikasikan dalam kurun waktu 2010-2019

2. Jurnal yang memenuhi standar publikasi dan mendapatkan nomor identifikasi jurnal atau jurnal seperti Digital Object Identifier (DOI), International Standard Serial Number (ISSN), dan International
Standard Book Number (ISBN).

3. Penelitian kualitatif dan kuantitatif (data primer)

4. Penelitian yang terkait dengan topik yang diteliti dilaksanakan di rumah sakit

5. Jurnal yang diterbitkan dengan menggunakan bahasa inggris Dalam systematic review ini, peneliti menggunakan beberapa jurnal yang diperoleh dari google scholar maupun proquest dan telah di telaah dalam bentuk systematic review. Dari 20 jurnal, pada variabel kualitas hidup, instrumen yang digunakan adalah Iranian Heart Failure Quality Of Life Questionnaire (1), Minnesota Living With Heart Failure Questionnaire (5), 36 Item Short Form Quality Of Life (5), Kansas City Cardiomyopathy Questionnaire (2) dan pada jurnal lainnya tidak ditemukan instrument yang digunakan untuk mengukur kualitas hidup. 


\section{Algoritma penelitian}

\section{Bagan 1 Diagram Kualitas Hidup Pasien Gagal Jantung Kongestif Proses}

Prisma

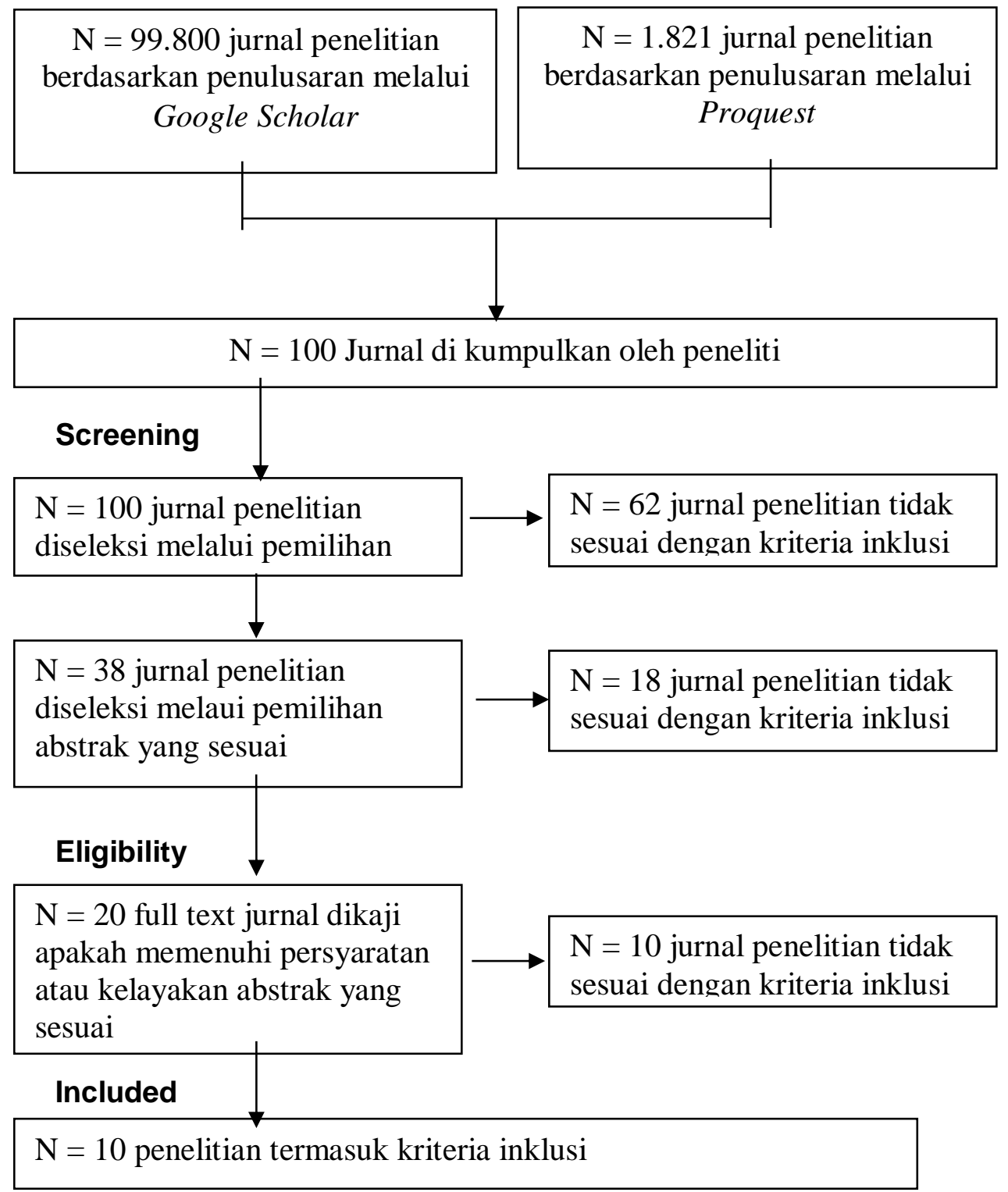


Tabel 1 Systematic Review Kualitas Hidup Pasien Gagal Jantung Kongestif

\begin{tabular}{|c|c|c|c|c|c|c|c|}
\hline No & Jurnal & Tujuan & Design & Sampel & $\begin{array}{c}\text { Instru- } \\
\text { ment }\end{array}$ & Hasil & Rekomendasi \\
\hline 1 & $\begin{array}{l}\text { Nesbitt, T., } \\
\text { Doctorvaladan, S., } \\
\text { Southard, J. A., Singh, } \\
\text { S., Fekete, A., Marie, K., } \\
\text { \& Cooper, L. (2014). } \\
\text { Correlates of quality of } \\
\text { life in rural patients with } \\
\text { heart failure. Circulation: } \\
\text { Heart Failure, 7(6), 882- } \\
887 . \\
\text { (CALIFORNIA UTARA) }\end{array}$ & $\begin{array}{l}\text { Penelitian ini } \\
\text { bertujuan untuk } \\
\text { mengetahui } \\
\text { tentang } \\
\text { Pengalaman } \\
\text { pasien } \\
\text { pedesaan } \\
\text { dengan gagal } \\
\text { jantung. }\end{array}$ & $\begin{array}{l}\text { Uji klinis } \\
\text { acak }\end{array}$ & $\begin{array}{l}\text { Pasien } \\
\text { Gagal } \\
\text { Jantung }\end{array}$ & $\begin{array}{l}\text { Minnesota } \\
\text { Living with } \\
\text { Heart } \\
\text { Failure }\end{array}$ & $\begin{array}{l}\text { Mayoritas adalah laki-laki } \\
(58,7 \%) \text {, menikah }(56,4 \%), \\
\text { dan telah menyelesaikan } \\
\text { sekolah menengah } \\
\text { Pendidikan (80,9\%). Faktor } \\
\text { yang terkait dengan } \\
\text { penurunan kualitas hidup di } \\
\text { antara populasi ini termasuk } \\
\text { lokasi geografis, yang lebih } \\
\text { muda } \\
\text { Usia, jenis kelamin laki-laki, } \\
\text { kelas New York Heart } \\
\text { Association yang lebih tinggi, } \\
\text { pengetahuan gagal jantung } \\
\text { yang lebih buruk, kontrol } \\
\text { yang dirasakan lebih buruk, } \\
\text { dan gejala depresi atau } \\
\text { kecemasan. }\end{array}$ & $\begin{array}{l}\text { Studi lebih lanjut, } \\
\text { menghubungkan } \\
\text { korelasi kualitas } \\
\text { hidup sebagaimana } \\
\text { ditentukan oleh } \\
\text { Penelitian ini } \\
\text { dengan ukuran } \\
\text { hasil seperti } \\
\text { kunjungan gawat } \\
\text { darurat, rawat inap, } \\
\text { dan kematian }\end{array}$ \\
\hline 2 & $\begin{array}{l}\text { Aggelopoulou, Z., Fotos, } \\
\text { N. V., Chatziefstratiou, A. } \\
\text { A., Giakoumidakis, K., } \\
\text { Elefsiniotis, I., \& } \\
\text { Brokalaki, H. (2017). The } \\
\text { level of anxiety, } \\
\text { depression and quality of } \\
\text { life among patients with } \\
\text { heart failure in } \\
\text { Greece. Applied Nursing } \\
\text { Research, 34, 52-56. }\end{array}$ & $\begin{array}{l}\text { Bertujuan untuk } \\
\text { menilai tingkat } \\
\text { kecemasan, } \\
\text { depresi dan } \\
\text { kualitas hidup } \\
\text { pasien gagal } \\
\text { jantung }\end{array}$ & $\begin{array}{l}\text { Studi } \\
\text { observasio } \\
\text { nal }\end{array}$ & $\begin{array}{l}231 \\
\text { pasien } \\
\text { gagal } \\
\text { jantung }\end{array}$ & $\begin{array}{l}\text { "Minnesota } \\
\text { Living with } \\
\text { Heart } \\
\text { Failure } \\
\text { Questionna } \\
\text { ire- } \\
\text { MLHFQ } \\
\text { untuk } \\
\text { mengukur } \\
\text { kualitas } \\
\text { hidup }\end{array}$ & $\begin{array}{l}\text { Hasil penelitian menunjukkan } \\
\text { kualitas hidup pasien sangat } \\
\text { rendah dan mereka } \\
\text { mengalami kecemasan yang } \\
\text { tinggi dan depresi yang } \\
\text { mempengaruhi penurunan } \\
\text { kualitas hidup. Selain itu, } \\
\text { kualitas hidup pasien } \\
\text { terpengaruh oleh faktor } \\
\text { ireversibel seperti usia, jenis } \\
\text { kelamin, dan status sosial } \\
\text { ekonomi. }\end{array}$ & $\begin{array}{l}\text { Menilai pasien } \\
\text { tersebut untuk } \\
\text { gejala-gejala ini } \\
\text { dan memberikan } \\
\text { perawatan } \\
\text { kesehatan holistik } \\
\text { oleh multidisiplin } \\
\text { tim, akan mengarah } \\
\text { pada pencegahan } \\
\text { dan perawatan dini } \\
\text { tidak hanya dari } \\
\text { manifestasi fisik } \\
\end{array}$ \\
\hline
\end{tabular}




\begin{tabular}{|c|c|c|c|c|c|c|c|}
\hline & (YUNANI) & & & & & & $\begin{array}{l}\text { tetapi juga } \\
\text { psikososial }\end{array}$ \\
\hline 3 & $\begin{array}{l}\text { Kikira, A., Koutelekos, I., } \\
\text { Parissopoulos, S., } \\
\text { Tsami, A., Fouka, G., \& } \\
\text { Polikandrioti, M. (2018). } \\
\text { Quality of life of } \\
\text { hospitalized patients with } \\
\text { heart failure, NYHA } \\
\text { IV. Archives of Hellenic } \\
\text { Medicine/Arheia } \\
\text { Ellenikes latrikes, 35(4). } \\
\text { YUNANI }\end{array}$ & $\begin{array}{l}\text { Untuk } \\
\text { mengeksplorasi } \\
\text { kualitas hidup } \\
\text { (kualitas hidup) } \\
\text { pasien yang } \\
\text { dirawat di rumah } \\
\text { sakit dengan } \\
\text { gagal jantung }\end{array}$ & $\begin{array}{l}\text { Kualitatif } \\
\text { (Interview) }\end{array}$ & $\begin{array}{l}\text { Pasien } \\
\text { gagal } \\
\text { jantung }\end{array}$ & $\begin{array}{l}\text { Minnesota } \\
\text { Living with } \\
\text { Heart } \\
\text { Failure }\end{array}$ & $\begin{array}{l}\text { Mengenai kualitas hidup, } \\
50 \% \text { dari pasien mendapat } \\
\text { skor di atas } 66 \text { (median) } \\
\text { pada skor total kualitas hidup } \\
\text { yang menunjukkan bahwa } \\
\text { gagal jantung berdampak } \\
\text { pada kualitas hidup pasien } \\
\text { yang buruk. Kualitas hidup } \\
\text { yang buruk ditunjukkan } \\
\text { dalam penelitian ini dikaitkan } \\
\text { dengan } \\
\text { kepatuhan yang rendah } \\
\text { terhadap pengobatan }\end{array}$ & \\
\hline 4 & $\begin{array}{l}\text { Hasanpour-Dehkordi, A., } \\
\text { Khaledi-Far, A., Khaledi- } \\
\text { Far, B., \& Salehi-Tali, S. } \\
\text { (2016). The effect of } \\
\text { family training and } \\
\text { support on the quality of } \\
\text { life and cost of hospital } \\
\text { readmissions in } \\
\text { congestive heart failure } \\
\text { patients in Iran. Applied } \\
\text { Nursing Research, 31, } \\
\text { 165-169. } \\
\text { (IRAN) }\end{array}$ & $\begin{array}{l}\text { Penelitian ini } \\
\text { dilakukan untuk } \\
\text { menyelidiki efek } \\
\text { dari pelatihan } \\
\text { dan dukungan } \\
\text { keluarga pada } \\
\text { kualitas hidup } \\
\text { Dan biaya } \\
\text { penerimaan } \\
\text { kembali di } \\
\text { rumah sakit } \\
\text { pada pasien } \\
\text { gagal jantung } \\
\text { kongestif. }\end{array}$ & $\begin{array}{l}\text { Uji acak } \\
\text { terkontrol }\end{array}$ & $\begin{array}{l}\text { Pasien } \\
\text { gagal } \\
\text { jantung } \\
\text { yang } \\
\text { dirawat di } \\
\text { rumah } \\
\text { sakit } \\
\text { Di rumah } \\
\text { sakit Iran }\end{array}$ & $\begin{array}{l}\text { Short Form } \\
-36 .\end{array}$ & $\begin{array}{l}\text { Intervensi perawatan } \\
\text { berdasarkan kolaborasi } \\
\text { pasien dan keluarga, yang } \\
\text { dirancang sesuai dengan } \\
\text { kebutuhan pasien, dan } \\
\text { modifikasi gaya hidup dapat } \\
\text { meningkatkan kondisi fisik, } \\
\text { mempromosikan kualitas } \\
\text { hidup dan efektif dalam } \\
\text { menurunkan penerimaan } \\
\text { kembali pada pasien. Dokter } \\
\text { di antara pasien jantung } \\
\text { Temuan Dari penelitian ini } \\
\text { dapat diterapkan untuk } \\
\text { mempromosikan pendidikan } \\
\text { keperawatan Pelajar, tenaga } \\
\text { keperawatan, tim } \\
\text { pengawasan dan klien. } \\
\text { Sebagai tambahan, }\end{array}$ & $\begin{array}{l}\text { Temuan dari } \\
\text { penelitian ini dapat } \\
\text { diterapkan untuk } \\
\text { mempromosikan } \\
\text { pendidikan } \\
\text { keperawatan } \\
\text { Pelajar, tenaga } \\
\text { keperawatan, tim } \\
\text { pengawasan dan } \\
\text { klien. Sebagai } \\
\text { tambahan, } \\
\text { Hasil ini dapat } \\
\text { menjadi dasar dari } \\
\text { program perawatan } \\
\text { kesehatan untuk } \\
\text { pasien CHF, } \\
\text { Keluarga dan } \\
\text { pengasuh mereka. }\end{array}$ \\
\hline
\end{tabular}




\begin{tabular}{|c|c|c|c|c|c|c|c|}
\hline & & & & & & $\begin{array}{l}\text { Hasil ini dapat menjadi dasar } \\
\text { dari program perawatan } \\
\text { kesehatan untuk pasien } \\
\mathrm{CHF} \text {, } \\
\text { Keluarga dan pengasuh } \\
\text { mereka. }\end{array}$ & \\
\hline 5 & $\begin{array}{l}\text { AbuRuz, M. E. (2018). } \\
\text { Anxiety and depression } \\
\text { predicted quality of life } \\
\text { among patients with } \\
\text { heart failure. Journal of } \\
\text { multidisciplinary } \\
\text { healthcare, 11, } 367 . \\
\text { YORDANIA }\end{array}$ & $\begin{array}{l}\text { Tujuan dari } \\
\text { penelitian ini } \\
\text { adalah untuk } \\
\text { menguji } \\
\text { pengaruh } \\
\text { kecemasan dan } \\
\text { depresi pada } \\
\text { kualitas hidup di } \\
\text { antara Pasien } \\
\text { dengan gagal } \\
\text { jantung di } \\
\text { Yordania. }\end{array}$ & $\begin{array}{l}\text { Cross } \\
\text { Sectional }\end{array}$ & $\begin{array}{l}\text { Pasien } \\
\text { gagal } \\
\text { jantung }\end{array}$ & $\begin{array}{l}\text { Short Form } \\
-36 .\end{array}$ & $\begin{array}{l}\text { Hasil penelitian menunjukkan } \\
\text { bahwa pasien dengan HF } \\
\text { memiliki kualitas hidup yang } \\
\text { buruk pada domain fisik } \\
\text { maupun mental. }\end{array}$ & $\begin{array}{l}\text { Hasil dari penelitian } \\
\text { ini memberikan } \\
\text { dukungan lebih } \\
\text { lanjut untuk } \\
\text { kesimpulan } \\
\text { sebelumnya } \\
\text { bahwa pasien } \\
\text { dengan gagal } \\
\text { jantung memiliki } \\
\text { kualitas hidup yang } \\
\text { buruk. Selain itu, } \\
\text { pencantuman } \\
\text { penilaian rutin } \\
\text { dan manajemen } \\
\text { kecemasan dan } \\
\text { depresi dalam } \\
\text { protokol HF } \\
\text { sangat dianjurkan. }\end{array}$ \\
\hline 6 & $\begin{array}{l}\text { Aburuz, M. E., Alaloul, } \\
\text { F., Saifan, A., Masa'Deh, } \\
\text { R., \& Abusalem, S. } \\
\text { (2016). Quality of life for } \\
\text { Saudi patients with heart } \\
\text { failure: a cross-sectional } \\
\text { correlational } \\
\text { study. Global journal of } \\
\text { health science, 8(3), } 49 .\end{array}$ & $\begin{array}{l}\text { Untuk menilai } \\
\text { kualitas hidup } \\
\text { pasien gagal } \\
\text { jantung di Saudi } \\
\text { Arabia }\end{array}$ & $\begin{array}{l}\text { Cross } \\
\text { Sectional }\end{array}$ & $\begin{array}{l}\text { Pasien } \\
\text { gagal } \\
\text { jantung }\end{array}$ & $\begin{array}{l}\text { Short Form } \\
-36 .\end{array}$ & $\begin{array}{l}\text { Pasien gagal jantung di } \\
\text { Saudi Arabia melaporkan } \\
\text { kualitas hidup yang buruk } \\
\text { disemua domain baik secara } \\
\text { fisik maupun mental. Pasien } \\
\text { dengan usia yang lebih tua, } \\
\text { memiliki kualitas hidup yang } \\
\text { paling rendah, Hal ini } \\
\text { menunjukkan perlunya } \\
\text { perhatian dan manajemen }\end{array}$ & $\begin{array}{l}\text { Perawatan holistik } \\
\text { untuk pasien gagal } \\
\text { jantung oleh tim } \\
\text { multidisiplin } \\
\text { profesional } \\
\text { perawatan } \\
\text { kesehatan dan } \\
\text { keluarga dapat } \\
\text { meningkatkan } \\
\text { kualitas hidup }\end{array}$ \\
\hline
\end{tabular}




\begin{tabular}{|c|c|c|c|c|c|c|c|}
\hline & (SAUDI ARABIA) & & & & & lebih lanjut. & mereka. \\
\hline 7 & $\begin{array}{l}\text { Alaloul, F., AbuRuz, M. } \\
\text { E., Moser, D. K., Hall, L. } \\
\text { A., \& Al-Sadi, A. (2017). } \\
\text { Factors associated with } \\
\text { quality of life in Arab } \\
\text { patients with heart } \\
\text { failure. Scandinavian } \\
\text { journal of caring } \\
\text { sciences, 31(1), 104- } \\
111 . \\
\text { ARAB }\end{array}$ & $\begin{array}{l}\text { Tujuan dari } \\
\text { penelitian ini } \\
\text { adalah untuk } \\
\text { menguji } \\
\text { hubungannya } \\
\text { karakteristik } \\
\text { demografis, } \\
\text { variabel medis } \\
\text { dan persepsi } \\
\text { dukungan sosial } \\
\text { dengan kualitas } \\
\text { hidup (QOL) } \\
\text { dalam bahasa } \\
\text { Arab } \\
\text { penderita gagal } \\
\text { jantung. }\end{array}$ & $\begin{array}{l}\text { Cross } \\
\text { sectioanl }\end{array}$ & $\begin{array}{l}\text { Pasien } \\
\text { gagal } \\
\text { jantung }\end{array}$ & $\begin{array}{l}\text { Short Form } \\
-36 .\end{array}$ & $\begin{array}{l}\text { Skor rata-rata untuk domain } \\
\text { QOL disajikan di } \\
\text { Tabel 3. Secara keseluruhan, } \\
\text { skor pasien rendah untuk } \\
\text { semua domain yang } \\
\text { menunjukkan kualitas hidup } \\
\text { yang buruk. Skor rata-rata } \\
\text { terendah } \\
\text { adalah untuk vitalitas (mis. } \\
\text { kurangnya energi dan } \\
\text { kehadiran kelelahan), } \\
\text { sedangkan skor kesehatan } \\
\text { mental mereka adalah yang } \\
\text { tertinggi. } \\
\text { Para pasien melaporkan } \\
\text { masalah dengan melakukan } \\
\text { mereka } \\
\text { peran biasa karena } \\
\text { kesehatan fisik yang buruk, } \\
\text { tubuh yang signifikan } \\
\text { rasa sakit dan keterbatasan } \\
\text { melakukan aktivitas peran. }\end{array}$ & $\begin{array}{l}\text { Karena pentingnya } \\
\text { memahami kualitas } \\
\text { hidup dan } \\
\text { penentu dalam } \\
\text { konteks budaya, } \\
\text { hasil } \\
\text { dari studi ini dapat } \\
\text { memberikan } \\
\text { panduan berharga } \\
\text { untuk perawatan } \\
\text { kesehatan } \\
\text { penyedia di negara- } \\
\text { negara Arab serta } \\
\text { Barat } \\
\text { masyarakat dalam } \\
\text { merawat pasien ini. } \\
\text { Studi selanjutnya } \\
\text { adalah } \\
\text { diperlukan untuk } \\
\text { mengeksplorasi } \\
\text { hubungan antara } \\
\text { dukungan sosial } \\
\text { dan kualitas hidup } \\
\text { di antara pasien } \\
\text { dengan gagal } \\
\text { jantung di } \\
\text { Budaya Arab. }\end{array}$ \\
\hline 8 & $\begin{array}{l}\text { Hayeah, H. M. A., } \\
\text { Saifan, A. R., aburuz, M. } \\
\text { E., \& Aljabery, M. A. } \\
\text { (2017). Health-Related }\end{array}$ & $\begin{array}{l}\text { Untuk } \\
\text { mengeksplorasi } \\
\text { kualitas hidup } \\
\text { pasien dengan }\end{array}$ & Kualitatif & $\begin{array}{l}\text { Pasien } \\
\text { gagal } \\
\text { jantung }\end{array}$ & Recorder & $\begin{array}{l}\text { Kualitas hidup terkait } \\
\text { kesehatan adalah konsep } \\
\text { multidimensi dan subjektif } \\
\text { yang dipengaruhi oleh }\end{array}$ & $\begin{array}{l}\text { Oleh karena itu, } \\
\text { studi lebih lanjut } \\
\text { direkomendasikan } \\
\text { untuk memberikan }\end{array}$ \\
\hline
\end{tabular}




\begin{tabular}{|c|c|c|c|c|c|c|c|}
\hline & $\begin{array}{l}\text { Quality of Life in Heart } \\
\text { Failure in Jordan from } \\
\text { Patient's Perspectives. } \\
\text { YORDANIA }\end{array}$ & $\begin{array}{l}\text { gagal jantung di } \\
\text { Yordania }\end{array}$ & & & & $\begin{array}{l}\text { berbagai faktor. Gagal } \\
\text { jantung memiliki dampak } \\
\text { negatif pada kualitas hidup } \\
\text { pasien, terutama dalam } \\
\text { domain fisik. }\end{array}$ & $\begin{array}{l}\text { dukungan efektif } \\
\text { bagi mereka yang } \\
\text { menderita secara } \\
\text { ekonomi }\end{array}$ \\
\hline 9 & $\begin{array}{l}\text { Audi, G., Korologou, A., } \\
\text { Koutelekos, I., } \\
\text { Vasilopoulos, G., } \\
\text { Karakostas, K., } \\
\text { Makrygianaki, K., \& } \\
\text { Polikandrioti, M. (2017). } \\
\text { Factors affecting health } \\
\text { related quality of life in } \\
\text { hospitalized patients with } \\
\text { heart failure. Cardiology } \\
\text { research and practice. } \\
\text { (YUNANI) }\end{array}$ & $\begin{array}{l}\text { Studi ini } \\
\text { mengidentifikasi } \\
\text { faktor-faktor } \\
\text { yang } \\
\text { mempengaruhi } \\
\text { kualitas hidup } \\
\text { terkait } \\
\text { kesehatan } \\
\text { (HRQOL) pada } \\
300 \text { pasien } \\
\text { rawat inap } \\
\text { dengan gagal } \\
\text { jantung (HF). }\end{array}$ & $\begin{array}{l}\text { Cross- } \\
\text { sectional }\end{array}$ & $\begin{array}{l}300 \\
\text { pasien } \\
\text { rawat } \\
\text { inap } \\
\text { dengan } \\
\text { gagal } \\
\text { jantung } \\
\text { (gagal } \\
\text { jantung). }\end{array}$ & $\begin{array}{l}\text { Minnesota } \\
\text { Living with } \\
\text { Heart } \\
\text { Failure } \\
\text { Questionna } \\
\text { ire } \\
\text { (MLHFQ) }\end{array}$ & $\begin{array}{l}\text { Jurnal ini meneliti } 300 \text { pasien } \\
\text { gagal jantung dirawat di } \\
\text { rumah sakit di Yunani. } \\
\text { Tabel } 3 \text { menyajikan hasil } \\
\text { yang berkaitan dengan } \\
\text { kualitas hidup pasien. } \\
\text { Diamati bahwa setidaknya } \\
50 \% \text { pasien memiliki skor di } \\
\text { bawah } 46 \text { (median) } n \text { dalam } \\
\text { skor total kualitas hidup, } 22 \\
\text { dalam skor fisik dan } 6 \text { dalam } \\
\text { skor mental. Nilai-nilai ini } \\
\text { menunjukkan efek gagal } \\
\text { jantung yang moderat dalam } \\
\text { kualitas hidup pasien. Skor } \\
\text { total untuk kualitas hidup } \\
\text { secara statistik signifikan } \\
\text { terkait dengan tingkat } \\
\text { pendidikan }(p=0,002), \\
\text { pekerjaan }(p<0,001), \text { dan } \\
\text { tempat tinggal }(p<0,001)\end{array}$ & $\begin{array}{l}\text { Dokter harus } \\
\text { mempertahankan } \\
\text { dan fokus dalam } \\
\text { mengobati } \\
\text { penyakit, } \\
\text { memaksimalkan } \\
\text { harapan hidup, dan } \\
\text { mengoptimalkan } \\
\text { kualitas hidup } \\
\text { pasien gagal } \\
\text { jantung }\end{array}$ \\
\hline 10 & $\begin{array}{l}\text { Hwang, S. L., Liao, W. } \\
\text { C., \& Huang, T. Y. } \\
\text { (2014). Predictors of } \\
\text { quality of life in patients } \\
\text { with heart failure. Japan } \\
\text { Journal of Nursing } \\
\text { Science, 11(4), 290-298. }\end{array}$ & $\begin{array}{l}\text { Untuk } \\
\text { memahami } \\
\text { kualitas hidup } \\
\text { dan efek } \\
\text { sosiodemografi, } \\
\text { keparahan } \\
\text { penyakit, fisik }\end{array}$ & $\begin{array}{l}\text { Cross } \\
\text { sectional }\end{array}$ & $\begin{array}{l}\text { Pasien } \\
\text { dengan } \\
\text { gagal } \\
\text { jantung }\end{array}$ & $M L H F Q$ & $\begin{array}{l}\text { Usia, waktu didiagnosis } \\
\text { gagal jantung, gejala fisik, } \\
\text { dan depresi adalah prediktor } \\
\text { penting kualitas hidup di } \\
\text { Pasien gagal jantung. } \\
\text { Intervensi yang menargetkan } \\
\text { gejala fisik dan depresi }\end{array}$ & $\begin{array}{l}\text { Temuan dari } \\
\text { Studi saat ini } \\
\text { menunjukkan } \\
\text { bahwa intervensi } \\
\text { mengurangi gejala } \\
\text { fisik dan depresi } \\
\text { pasien dengan }\end{array}$ \\
\hline
\end{tabular}




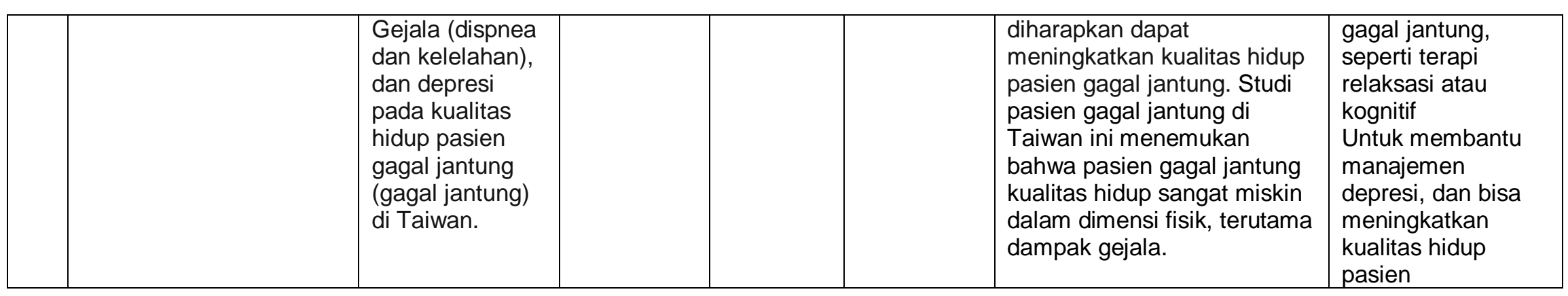


HASIL

Systematic review ini dimulai dengan mencari beberapa jurnal yang diterbitkan dalam bahasa inggris yang berkaitan dengan kualitas hidup pasien gagal jantung kongestif dan ditemukan ratusan referensi. Pencarian referensi terbatas pada jurnal yang diterbitkan antara tahun 2010-2019. Dalam hasil pencarian melalui google scholar dan proquest, ditemukan 100 jurnal yang menjelaskan tentang kualitas hidup pasien gagal jantung kongestif. Data yang relevan diekstrak dengan memilih jurnal yang sesuai dengan kriteria inklusi/eksklusi yang telah ditetapkan untuk kemudian dilakukan sintesis narasi.

Dari 100 jurnal, peneliti mengambil 10 jurnal terkait kualitas hidup yang sesuai dengan kriteria inklusi yang telah ditetapkan oleh peneliti. Pada variabel kualitas hidup, instrumen yang digunakan adalah Iranian Heart Failure Quality Of Life Questionnaire (1), Minnesota Living With Heart Failure Questionnaire (5), 36 Item Short Form Quality Of Life (5), Kansas City Cardiomyopathy Questionnaire (2) dan pada jurnal lainnya tidak ditemukan instrument yang digunakan untuk mengukur kualitas hidup.

Aggelopoulou et al (2017) menyatakan bahwa kualitas hidup pasien gagal jantung kongestif adalah buruk, karena skor rata-rata MLHFQ adalah $65,4 \pm 20,6$. Pasien juga mengalami kecemasan tingkat tinggi dan bahkan ada yang depresi [13]. Demikian halnya penelitian AbuRuz et al (2016), menyatakan bahwa skor kualitas Hidup pasien gagal jantung kongestif adalah rendah. menunjukkan kualitas hidup yang buruk [14]. Audi et al (2017) juga menyatakan bahwa $50 \%$ pasien memiliki skor di bawah 46 (median) $n$ dalam skor total kualitas hidup, 22 dalam skor fisik dan 6 dalam skor mental. Nilai-nilai ini menunjukkan efek gagal jantung yang moderat dalam kualitas hidup pasien [15]

Hwang, S. L., Liao, W. C., \& Huang, T. Y., (2014) meneliti pasien dengan gagal jantung di Taiwan menemukan bahwa kualitas hidup mereka sangat rendah dalam dimensi fisik. Demikian juga, skor kualitas hidup dimensi emosional adalah 5,6 \pm 5,8, termasuk item: membuat pasien khawatir; kesulitan dalam berkonsentrasi atau mengingat sesuatu; merasa seperti menjadi beban untuk keluarganya; merasa kehilangan kontrol diri hidupnya; dan merasa tertekan [16].

Sementara penelitian yang dilakukan Hayeah et al (2017) di Yordania menunjukkan bahwa gagal jantung memiliki dampak negatif pada kualitas hidup pasien, terutama dalam domain fisik [17].

Kikira et all (2018) menyatakan bahwa kualitas hidup yang buruk ditunjukkan dalam penelitian ini dikaitkan dengan kepatuhan yang rendah terhadap pengobatan [18]. AbuRuz, M. E., (2018) pun melaporkan kualitas hidup yang buruk pada dimensi fisik dan mental. Hasil penelitian yang dilakukan oleh Alaloul et al (2017) dan Hansapour (2016) menunjukkan bahwa kualitas hidup menurun pada pasien dengan penyakit gagal jantung kongestif [19]. Sama halnya dengan pernyataan Nesbit (2014) dalam penelitiannya yang menunjukkan penurunan kualitas hidup pada pasien gagal jantung. Kualitas hidup yang rendah di pengaruhi oleh lokasi geografis, usia yang lebih muda, jenis kelamin, tingkat NHYA yang lebih tinggi, pengetahuan, gejala depresi dan kecemasan [20]. 


\section{PEMBAHASAN}

Berdasarkan systematic review di atas, dari 10 jurnal yang ditelaah peneliti terkait kualitas hidup pasien gagal jantung kongestif, ditemukan 10 buah (100\%) jurnal yang menyatakan bahwa kualitas hidup pasien gagal jantung kongestif dalam kategori buruk/rendah. Gagal jantung memiliki dampak negatif pada kualitas hidup pasien. Hal ini dikarenakan gagal jantung merupakan penyakit kronis dengan prognosis yang buruk.

Gagal jantung adalah suatu kondisi yang terjadi ketika jantung tidak dapat berespons secara adekuat terhadap stress untuk memenuhi kebutuhan metabolik tubuh. Pada kondisi ini, jantung tidak mampu untuk melaksanakan tugasnya sebagai pemompa darah. Gagal jantung kongestif adalah keadaan ketika jantung tidak mampu lagi memompakan darah secukupnya dalam memenuhi kebutuhan sirkulasi tubuh untuk keperluan metabolisme jaringan tubuh pada kondisi tertentu, sedangkan tekanan pengisian ke dalam jantung masih cukup tinggi [3].

Hasil penelitian yang dilakukan oleh Aggelopoulou et al (2017), disampaikan bahwa kualitas hidup pasien gagal jantung sangat rendah dan mereka mengalami kecemasan dan depresi yang tinggi yang mempengaruhi penurunan kualitas hidup [13]. Hal yang sama juga disampaikan oleh Hayeah et al (2017), bahwa gagal jantung memiliki dampak negatif pada kualitas hidup pasien, terutama dalam domain fisik [17]. Pendapat ini didukung oleh AbuRuz et al (2016), yang mengatakan bahwa pasien gagal jantung di Saudi Arabia memiliki kualitas hidup yang buruk disemua domain baik secara fisik maupun mental [14]. Audi et al (2017) juga mengatakan bahwa setidaknya $50 \%$ pasien memiliki skor di bawah 46 (median) $n$ dalam skor total kualitas hidup, 22 dalam skor fisik dan 6 dalam skor mental. Nilainilai ini menunjukkan efek gagal jantung yang moderat dalam kualitas hidup pasien [15].

$$
\text { Gagal jantung kongestif }
$$

merupakan penyakit dengan prognosis yang buruk. Dampak dari gagal jantung kongestif seperti kelelahan, sesak nafas dan ketidakmampuan pasien melakukan aktivitas seperti orang lain yang hidup sehat, akan menimbulkan masalah baru seperti depresi bagi pasien yang berpengaruh pada kesehatan mental dan akan berdampak buruk pada kualitas hidupnya [21]. Kualitas hidup yang buruk atau rendah merupakan kondisi atau keadaan yang tidak optimal ditandai dengan keterbatasan melakukan aktivitas ringan maupun berat, merasa depresi/cemas dan tidak berguna, merasa menjadi beban keluarga, dan kehilangan harapan.

\section{SIMPULAN DAN SARAN}

Berdasarkan hasil systematic review diatas, peneliti menyimpulkan bahwa dari 10 jurnal yang ditelaah peneliti terkait kualitas hidup pasien gagal jantung kongestif, ditemukan 10 buah (100\%) jurnal yang menyatakan bahwa kualitas hidup pasien gagal jantung kongestif dalam kategori buruk/rendah.

Berdasarkan hasil telaah yang dilakukan oleh peneliti, dari 8 jurnal yang ditelaah ditemukan sebanyak 6 buah jurnal (75\%) yang mengatakan bahwa manajemen diri erat kaitannya dengan kualitas hidup pasien gagal jantung kongestif.

$$
\text { Peneliti menyimpulkan }
$$

bahwa manajemen diri sangat 
penting dan sangat diperlukan untuk membantu meningkatkan perawatan diri secara mandiri pasien gagal jantung kongestif, sehingga memungkinkan pasien untuk berperan aktif dalam mengelola kondisi kesehatan mereka yang bermanfaat untuk meningkatkan kualitas mereka.

Peneliti menyarankan kepada peneliti selanjutnya untuk meneliti tentang pengaruh manajemen diri terhadap kualitas hidup pasien gagal jantung kongestif. Diharapkan dengan memberikan edukasi mampu membantu untuk meningkatkan pengetahuan pasien gagal jantung kongestif tentang manajemen diri yang baik sehingga kemampuan manajemen diri pasien gagal jantung kongestif akan meningkat dan dapat membantu individu untuk meningkatkan kualitas hidupnya.

\section{DAFTAR PUSTAKA}

1. Adebayo, S., Olunuga, T., Durodola, A., \& Ogah, O. (2017). Heart failure: Definition, classifycation, and pathophysiology - A mini-review. Nigerian Jour-nal of Cardiology, 14(1), 9. https://doi.org/10.4103/0189$\underline{7969.201913}$

2. Yancy, C. W., et al. (2013). 2013 ACCF/AHA guideline for the management of heart failure: Executive summary: A report of the American college of cardiology oundation/american heart association task force on practice guidelines. Journal of the American College of Cardiology, 62(16), 1495

3. Aspiani, R. Y. (2014). Buku Ajar Asuhan Keperawatan Klien Gangguan Kardiovaskuler:
Aplikasi NIC \& NOC. Jakarta : EGC

4. Baert, A., De Smedt, D., De Sutter, J., De Bacquer, D., Puddu, P. E., Clays, E., \& Pardaens, S. (2018). Factors associated with health-related quality of life in stable ambulatory congestive heart failure patients: Systematic review. European Journal of Preventive Cardiology, 25(5), 472-481. https://doi.org/10.1177/20474873 $\underline{18755795}$

5. Chaparro, Sandra (2019). Updates in Advanced Heart Failure 2019. University of Miami< Miller School of Medicine

6. Kemenkes RI (2013). Info Datin Pusat Data dan Informasi Kementerian Kesehatan RI.

7. Junita, D. T. (2017). Profil Pasien Gagal Jantung Kongestif di RSUP Haji Adam Malik Medan Periode Juli hingga Desember Tahun 2016.

8. Rosa, M., Armenia, A., \& Almasdy, D. (2015). Dampak Karakteristik Sosiodemografi dan Tingkat Kepatuhan Terapi Antihipertensi Terhadap HRQoL Pasien Gagal Jantung Kongestif. Jurnal Sains Farmasi \& Klinis, 2(1), 40. https://doi.org/10.29208/jsfk.2015 .2 .1 .50

9. Fadli, F. (2017). Pengaruh Latihan Nafas Dalam Terhadap Sensitivitas Barorfleks Arteri Pada Klien Gagal Jantung Kongestif Di Rsud Labuang Baji Kota Makassar. Jurnal IImiah Kesehatan Diagnosis, 9(2), 222226. 
10. Kristinawati, B., \& Khasanah, R. N. (2019). Hubungan Pelaksanaan Edukasi dengan Kemampuan Self Care Management Pasien Gagal Jantung. Proceeding of The URECOL, 496-503.

11. Djamaludin, D., Tua, R., \& Deria, D. (2018). Hubungan Self Care Terhadap Kualitas Hidup Pada Klien Gagal Jantung Di poli Jantung RSUD Dr. H. Abdel Moeloek Provinsi Lampung Tahun 2017. Holistik Jurnal Kesehatan, 12(3), 178-188.

12. Tatukude, C., Rampengan, S. H., \& Panda, A. L. (2016). Hubungan Tingkat Depresi Dan Kualitas Hidup Pada Pasien Gagal Jantung Kronik Di Poliklinik Jantung Rsup Prof. Dr. R. D. Kandou Manado. E-CliniC, 4(1).

13. Aggelopoulou, Z., Fotos, N.V., Chatziefstratiou, A. A., Giakoumidakis, K., Elefsiniotis, I., \& Brokalaki, H. (2017). The level of anxiety, depression and quality of life among patients wuth heart failure in greece. Apllied Nursing Research, 34, 52-56

14. AbuRuz, M. E., Alaloul, F., Saifan, A., Masa'Deh, R., \& Abusalem, S. (2016). Quality of life for Saudi patients with heart failure: a cross-sectional correlational study. Global journal of health science, 8(3), 49.

15. Audi, G., Korologou, A., Koutelekos, I., Vasilopoulos, G., Karakostas, K., Makrygianaki, K., \& Polikandrioti, M. (2017). Factors affecting health related quality of life in hospitalized patients with heart failure. Cardiology research and practice.

16. Hwang, S. L., Liao, W. C., \& Huang, T. Y. (2014). Predictors of quality of life in patients with heart failure. Japan Journal of Nursing Science, 11(4), 290-298.

17. Hayeah, H. M. A., Saifan, A. R., AbuRuz, M. E., \& Aljabery, M. A. (2017). Health-Related Quality of Life in Heart Failure in Jordan from Patient's Perspectives.

18. Kikira, A., Koutelekos, I., Parissopoulos, S., Tsami, A., Fouka, G., \& Polikandrioti, M. (2018). Quality of life of hospitalized patients with heart failure, NYHA IV. Archives of Hellenic Medicine/Arheia Ellenikes latrikes, 35(4).

19. Hasanpour-Dehkordi, A., Khaledi-Far, A., Khaledi-Far, B., \& Salehi-Tali, S. (2016). The effect of family training and support on the quality of life and cost of hospital readmissions in congestive heart failure patients in Iran. Applied Nursing Research, 31, 165-169.

20. Nesbitt, T., Doctorvaladan, S., Southard, J. A., Singh, S., Fekete, A., Marie, K., \& Cooper, L. (2014). Correlates of quality of life in rural patients with heart failure. Circulation: Heart Failure, 7(6), 882-887

21. Akhmad, A. N. (2018). Kualitas hidup pasien Gagal Jantung Kongestif (GJK) berdasarkan karakteristik demografi. Jurnal Keperawatan Soedirman 11(1), 27-34. 